\title{
BLACKS IN THE ARMY AIR FORCES DURING WORLD WAR II: THE PROBLEM OF RACE RELATIONS
}

by

Alan M. Ogur

OFFICE OF AIR FORCE HISTORY

Washington DC

For sale by the Superintendent of Documents, U.S. Government Printing Office Washington, D.C. 20402 - Price $\$ 2.40$

Stock number 008-070-00378-3 